\title{
Retracted: Potassium channel ether à go-gol is aberrantly expressed in human liposarcoma and promotes tumorigenesis
}

\section{BioMed Research International}

Received 5 December 2020; Accepted 5 December 2020; Published 2 February 2021

Copyright (c) 2021 BioMed Research International. This is an open access article distributed under the Creative Commons Attribution License, which permits unrestricted use, distribution, and reproduction in any medium, provided the original work is properly cited.

BioMed Research International has retracted the article titled "Potassium Channel Ether à go-gol Is Aberrantly Expressed in Human Liposarcoma and Promotes Tumorigenesis" [1], due to an error in the reported sequences.

It was raised to our attention [2] that the recombinant adenovirus control (Ad5-Control-shRNA) sequence, CTA GGT GTT CTA GTC TGG ACT, that was reported to be non-targeting actually targets glycophorin C (GYPC). The authors also did not discuss their previous related research, from which they reused around 1,500 words [3].

The authors could not be contacted.

\section{References}

[1] J. Wu, D. Zhong, Y. Wei, X. Wu, L. Kang, and Z. Ding, "Potassium channel ether à go-go 1 is aberrantly expressed in human liposarcoma and promotes tumorigenesis," BioMed Research International, vol. 2014, Article ID 345678, 12 pages, 2014, https://www.hindawi.com/journals/bmri/2014/345678/.

[2] C. Labbé, N. Grima, T. Gautier, B. Favier, and J. A. Byrne, "Semi-automated fact-checking of nucleotide sequence reagents in biomedical research publications: the seek \& Blastn tool," PLoS One, vol. 14, no. 3, article e0213266, 2019.

[3] J. Wu, D. Zhong, X. Fu, Q. Liu, L. Kang, and Z. Ding, "Silencing of Ether à Go-Go 1 by shRNA inhibits osteosarcoma growth and cell cycle progression," International Journal of Molecular Sciences, vol. 15, no. 4, pp. 5570-5581, 2014. 